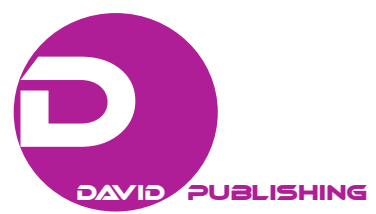

\title{
The Symbolism of the Skull in Vanitas: Homo Bulla Est ${ }^{*}$
}

\author{
Liana De Girolami Cheney \\ Universidad de Coruña, La Coruña, Spain
}

\begin{abstract}
In Dutch vanitas imagery of Homo bulla est there is a sad child (homo) holding a scalloped shell filled with soap and water. Although the child is amused and playing with the formation of beautiful transparent water circles, his expression is mischievous and melancholic. Blooming flowers and dead trees, burning urns, and cloudy landscapes also accompany this gloomy imagery, which alludes to a warning about moral behavior. The first part of this essay deals with a brief history about the symbolism of the skull in vanitas imagery (1590-1630). And the second part of the essay focuses on two prints by the Dutch artist and printmaker from Haarlem, Hendrick Goltzius (1558-1617), who honored this proverb Homo bulla est in Allegory of Transience as a remembrance of the brevity of life.
\end{abstract}

Keywords: moral symbolism, bubbles, emblems, putto, skull, scalloped shell, smoke, Dutch prints, Hendrick Goltzius, still-lifes, vanitas

\section{Introduction}

The image of the skull as a symbol of death is medieval in origin, unknown in this sense in antiquity (Causey, 1993; Hind, 1963). ${ }^{1}$ As a reminder of the transience of life on the Earth, the image of the skull found its place in vanitas paintings (Hall, 1974) ${ }^{2}$. These representations are depicted in religious paintings in penitent scenes and in secular paintings in still-lifes and portraits, including allegorical portraits, group portraits, single portraits, and self-portraits. The focus of this essay is to analyze the visual sources and emblematic meanings of the skull in late 16th and 17th century Dutch art. Sometimes, the single image of the skull with a figure or a portrait was referred to as Homo bulla est (Man [the individual] is a bubble). The disguised symbolism concealed in the display of the skull assists in the discovery of the key to meaning (clavis interpretandi) of the imagery and its didactic message about morals in human behavior.

A brief glance at early pictorial usages of the skull in particular in Northern Europe during the 16th and 17th centuries suggests several different traditions with varying shades of feeling, including humor, irony, terror, resignation, repentance, and remorse. Medieval allegorical subjects representing the hierarchical order of the universe and personifications of philosophical concepts, virtues, the arts, the planets and estates, and humors of the individual were available to European artists through humanist and popular literary and visual media. Among these were printed books, such as Petrarch's Triumphs and Ovide Moralisé; emblem books by

\footnotetext{
* Acknowledgement: I am grateful for the comments and suggestions of Drs. Donato Mansueto of Bari, Italy, and William Wanbaugh of Flint, Michigan.

Liana De Girolami Cheney, Ph.D., Visiting Researcher in Art History, the SIELAE, Universidad de Coruña, Spain.

1 In classical times, the quest was to seize the day or the moment, "carpe diem", meaning enjoy today because tomorrow may not come. A Latin expression noted by the Roman lyric poet Horace (65-8 BCE) in his Odes, 1.11.

2 The word "vanitas" derives from the Latin word vanus, meaning empty, which signifies the evanescence or futility of earthly goods and possessions. The term is encountered in Ecclesiastes 1:2; 12:8, Vanitas vanitatum, omnia vanitas, referring to the transitoriness of life.
} 
Andrea Alciato, Desiderius Erasmus Roterodamus, Hadrianus Junius, Roemer Visscher, Jacob Cats, and Cesare Ripa; prints of antiquities (classical monuments, sculptural, and coins); and playing cards (Tarocchi) (Panofsky, 1972). This kaleidoscopic medieval encyclopedia of images and meanings was associated with a humanistic atmosphere in Renaissance art, emphasizing the literary and scholastic revival of antiquity and provoking a fusion of symbols with various levels of interpretations.

The earliest representations of the skull in art (usually connected to a skeleton) are the totentanz or danse macabre, ars moriendi and the dance of death, often seen in response to the mass death scenes of the Black Death or bubonic plagues of 1348, 1361, and 1363 (see Figures 1, 2, and 3). These illustrations portrayed the medieval idea that all human beings are equal before death. In the dance of death, individual figures as skeletons are paired with their victims as seen in Totentanz of 1455, from the Codex Platinus Germanicus 438 (132r) at the University of Heidelberg in Germany (see Figure 1).

The concept of pairing living figures with death continues throughout the 16th century and into the 17th in Europe.

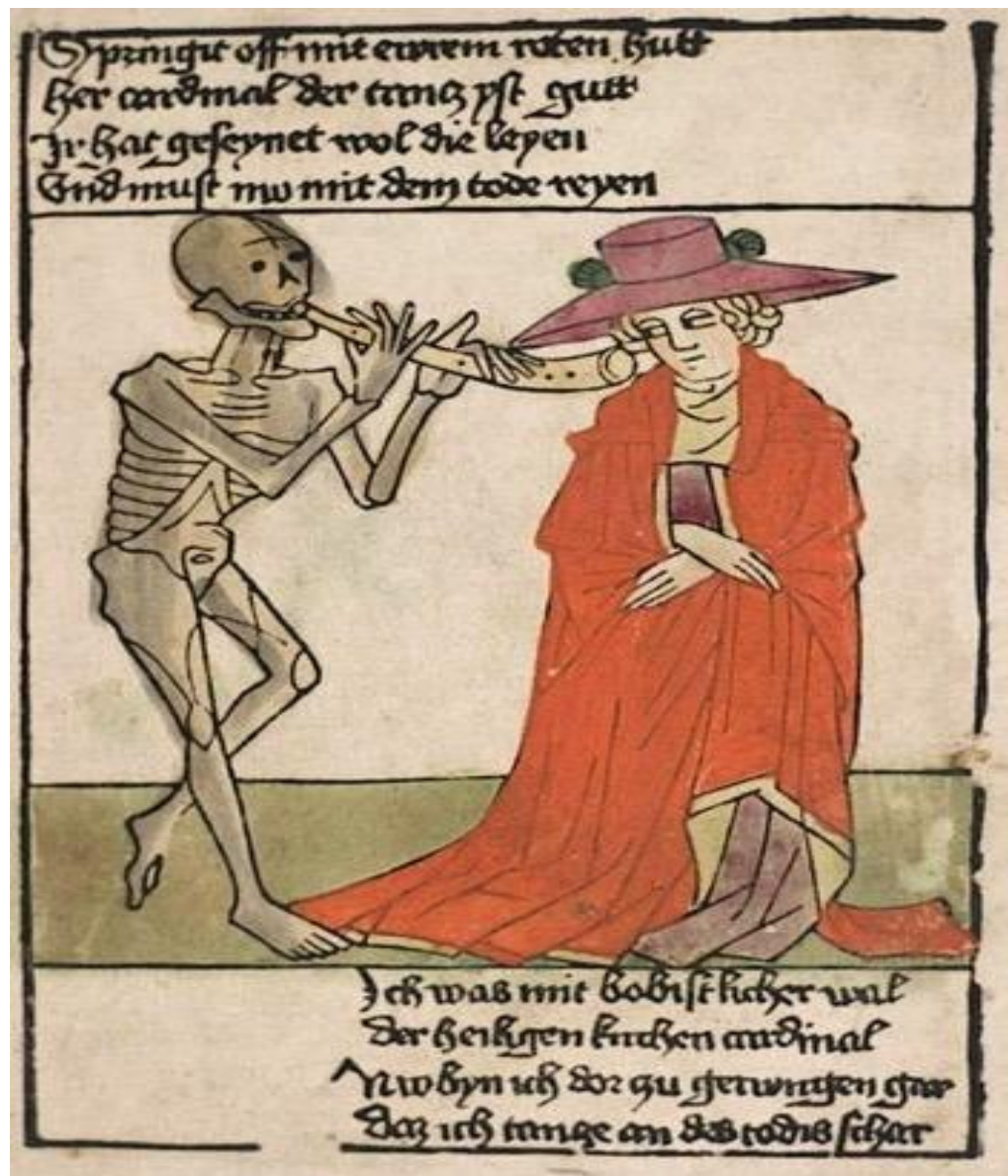

Figure 1. Totentanz, 1455, blockbook from the Codex Platinus Germanicus 438 (132r) at the University of Heidelberg, Germany (Photo credit: Public domain.commons.wikimedia.org). 


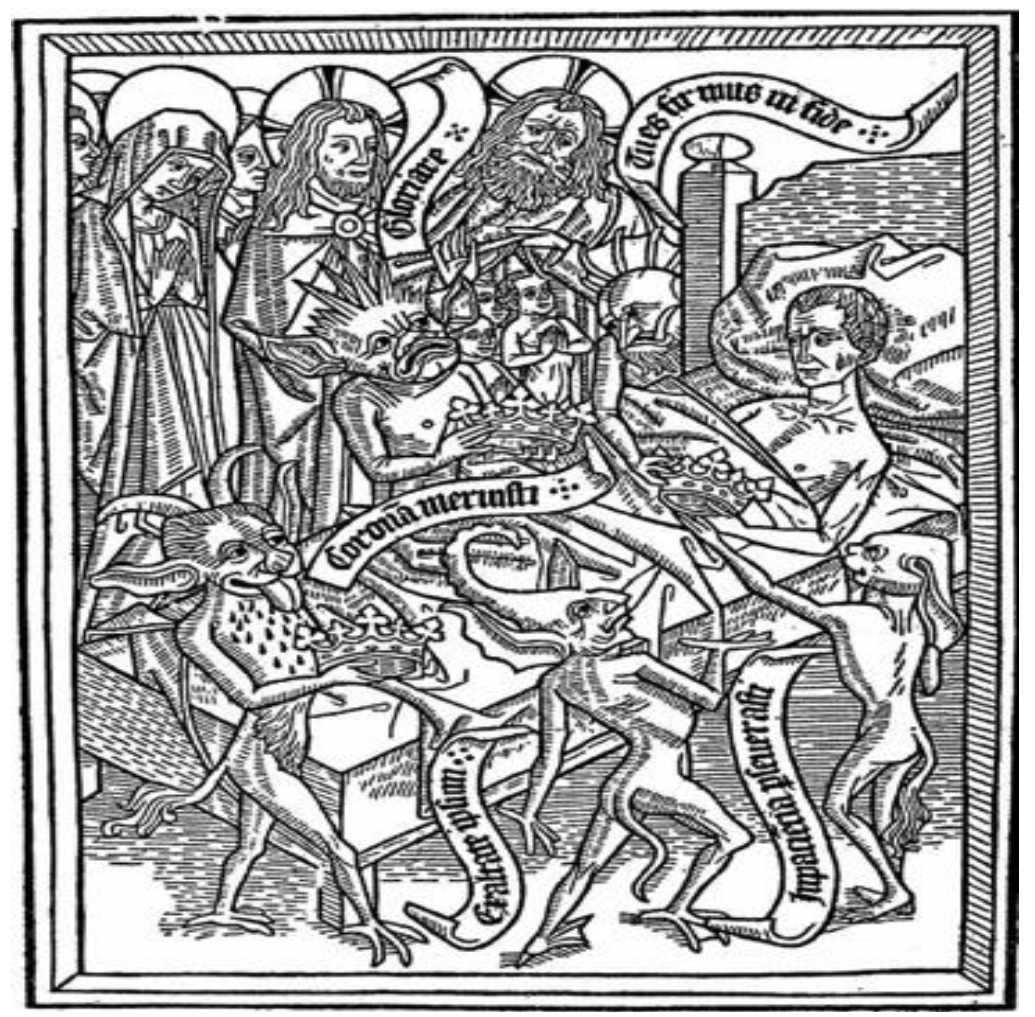

Figure 2. Master E. S., Ars Moriendi, 1464, woodcut from the Netherlandish Latin Text. Bibliothèque National of Paris (Photo credit: Public domain.wikipedia.org).

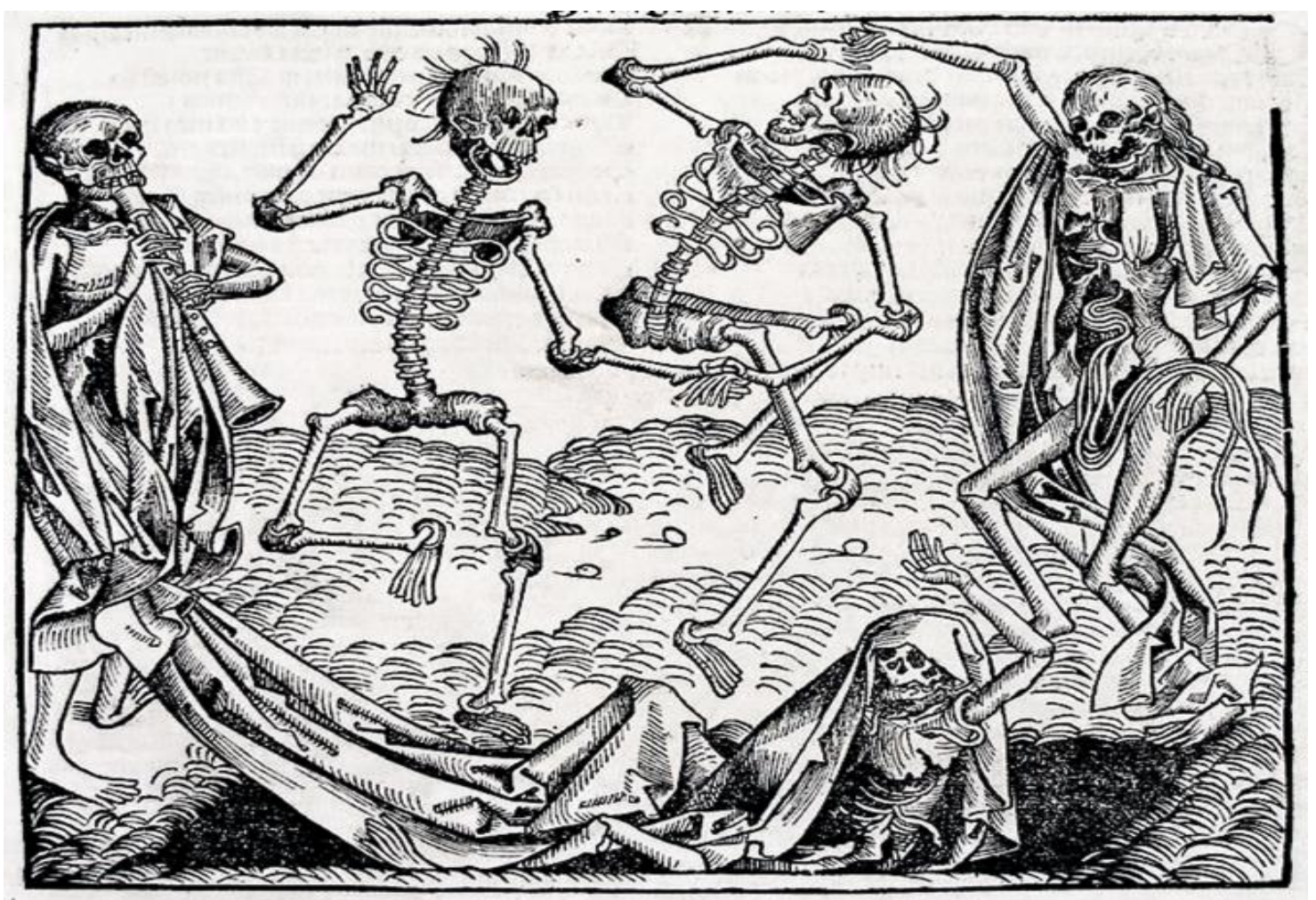

Figure 3. Michael Wolgenut, Dance of Death, 1493, woodcut from the Nuremberg Chronicles (Photo credit: Public domain.wikipedia.org). 
There is a difference between the ars moriendi and totentanz. The term ars moriendi signifies "the art of dying" and is related to a medieval collection of texts for the use of the clergy when attending to a dying person. The totentanz or danse macabre, also differs from the dance of death, as described above. During the medieval period, it was believed that the dead rose from their tombs at midnight and performed a dance in a graveyard before setting off to claims fresh victims from the living. Eventually, in the 14th and 15th centuries in Europe, these themes of ars moriendi, danse macabre, and the dance of death-along with texts describing contests between angels and demons over control of humans-were fused in the illustration tradition of woodcuts as seen in the Master E. S.'s Ars Moriendi of 1464, from the Netherlandish Latin Text, now in the Bibliothèque National of Paris (seer Figure 2); and Michael Wolgenut's Dance of Death from the Nuremberg Chronicles, published in 1493 (see Figure 3) (Clark, 2016; Boeckl, 1991) ${ }^{3}$. The illustrations usually show a procession marching or dancing to a grave, composed of a row of figures from all social ranks, organized in a hierarchical ladder of importance: the pope, the emperor, the cardinals, lesser ecclesiastics, persons of various occupations and ages, and finally peasants. All are accompanied by the figure of death in the form of a skeleton, symbolizing that time not only has passed away but has expired.

During the 16th century, with few exceptions, complex representations of a skeleton in ars moriendi, totentanz/danse macabre, and the dance of death merged and transformed into a single image, the skull. From then on, the image of the skull with all types of modifications and additional attributes makes it solo appearance as a memento mori (remember that you have to die) or vanitas (emptiness) symbol, directing the viewer to the end of life and away from its vanities or futilities. This imagery is noted by the Italian humanist, lawyer, and emblematist par excellence, Andrea Alciato (1492-1550), in his Emblem CLVII, In Mortem Praeproperam (Ultimately Death), which represents death with a skull instead of a skeleton, placed on a sarcophagus (see Figure 4) (Alciato, 1591; 1621). Alciato's Emblemata became a popular source for moral connotations in European humanistic and artistic circles (Alciato, 1591).

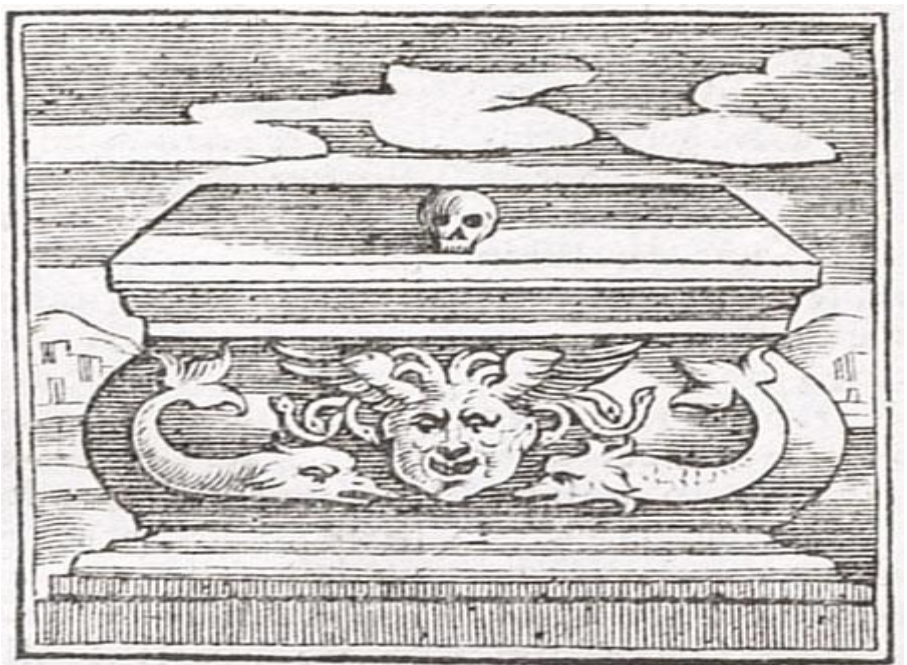

Figure 4. Andrea Alciato, Emblem CLVII, In Mortem Praeproperam (Ultimately Death). Emblemata (Padua: Petro Paulo Tozzi, 1621) (Photo credit: University of Glasgow, UK).

\footnotetext{
${ }^{3}$ See James M. Clark, This facsimile edition with an introduction and notes is about Hans Holbein the Younger's Dance of Death (1497-1543). This artist was instrumental in recording in his engravings many painted walls of cloisters and graveyards of the later Middle Ages that held representations of totentanz.
} 
The memento mori with the image of the skull appeared in religious representations of saints meditating or praying (Saint Jerome and Mary Magdalene) ${ }^{4}$ as well as in secular portraits and still-life paintings. These type of secular representations created two new genres called "vanitas portraits and vanitas still-lifes", which were very popular in images of the 17th century in Dutch art (Adams, 2013; Kelly, 2006; Alpers, 1984; Segal, 1989; Chong, 1999) ${ }^{5}$. While the skull was the most obvious reminder of mortality in this form of vanitas portraits and still-lifes, other symbols, such as mirrors, musical instruments, butterflies, flowers and insects, or a snuffed-out candle, also testified to the omnipresence of death (Schama, 1987) ${ }^{6}$. The skull was a motif that clearly symbolized the human certainty that the individual must die, alluding to the biblical symbolism of mortality in Ecclesiastes 1:2, "Vanitas vanitatum, omnia vanitas" (Vanity of vanities, all is vanity) (Hall, 1974; Haak, 1984), as seen in the woodcut of Urs Graf, Vanitas or Mercenary Love of 1511, woodcut after Hans Holbein the Younger (1497-1543), at the British Museum in London (1875, 0710.1455-AN94805400); and David Bailly's Vanitas With a Self-Portrait, 1651, at the Stedelijk Museum De Lakenhal, Leiden (see Figures 5 and 6).

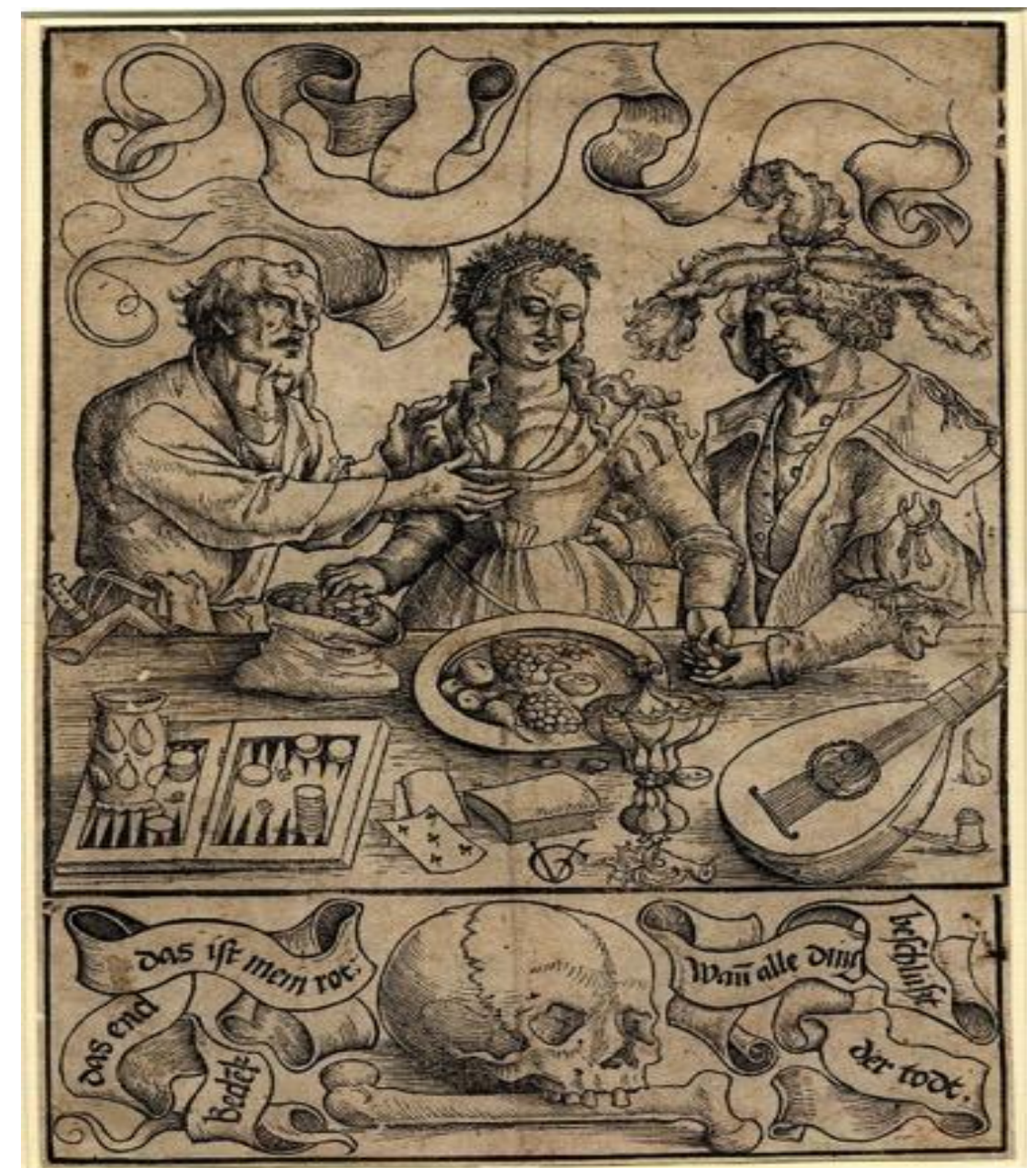

Figure 5. Urs Graf, Vanitas or Mercenary Love, 1511, woodcut after Hans Holbein the Younger. British Museum, London (Photo credit: British Museum, London [1875, 0710.1455-AN94805400]).

\footnotetext{
${ }^{4}$ For example, Gerrit Dou's Saint Jerome of 1660 at the Gemäldegalerie Alte Meister, Staatliche Kunstsammlunger in Dresden; and Jan de Bray, The Penitent Magdalene of 1670, in private collection.

5 This essay will focus only on some of the images of vanitas portraits.

${ }^{6}$ Other vanitas symbols were: crucifixes, clocks, coins, fruits, oil lamps, pipes, purses, shells, and hourglasses.
} 


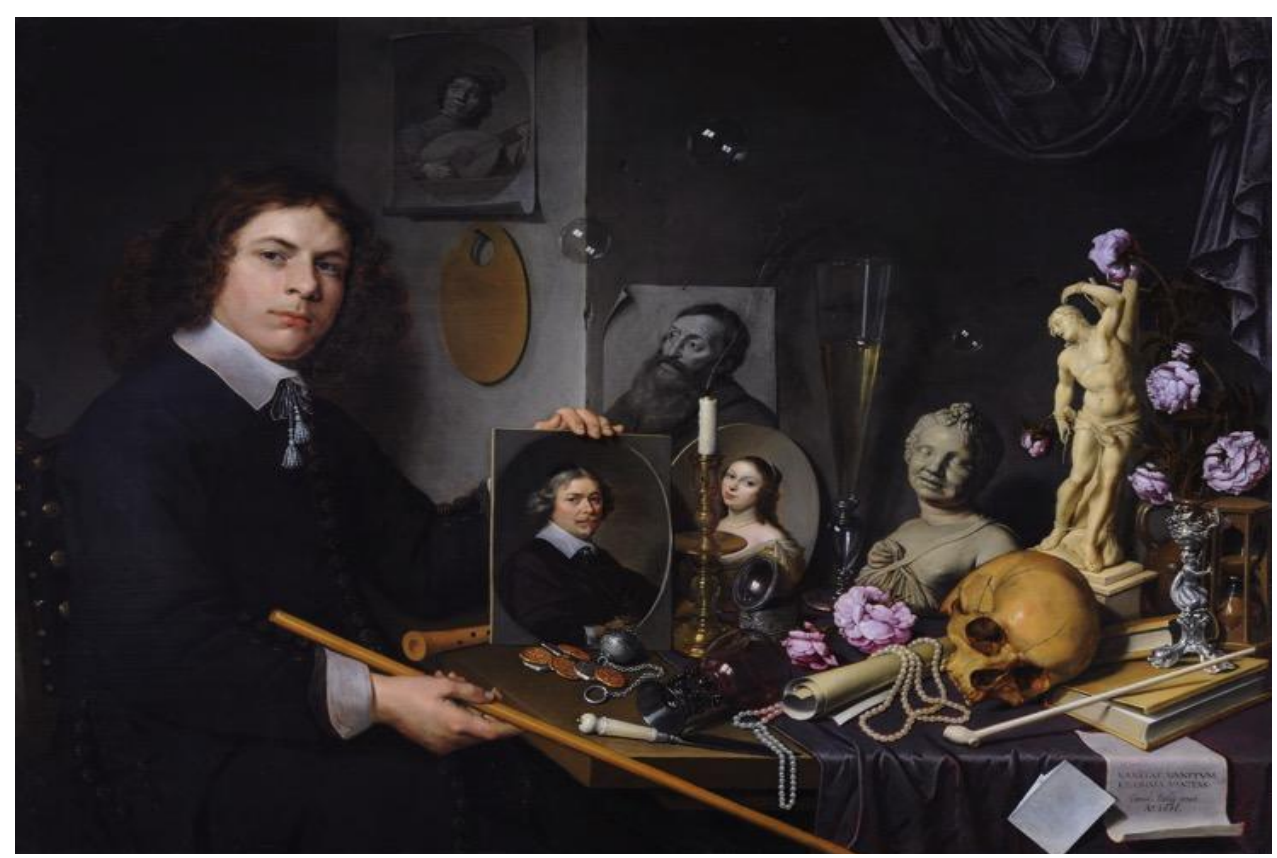

Figure 6. David Bailly, Vanitas With a Self-Portrait, 1651. Stedelijk Museum De Lakenhal, Leiden (Photo credit: Public domain.wikimedia.org).

In Dutch art the preoccupation with the meaning of life was characterized by art historian and iconographer Erik de Jong as the tendency of moralizing, as seen in vanitas portrait paintings, and was part of the mentality of 17th century. In the use of realism and double entendre in their imageries, Dutch artists were assisted by biblical and Dutch emblematic sources, such as Andrea Alciato's Emblemata translated into Dutch (Leiden, 1591), Roemer Visscher's Sinnepoppen (Amsterdam, 1614), Jacob Cats's Sinne-en-Minnebeelden (Amsterdam, 1627), and Cesare Ripa's Iconologia translated into Dutch (Amsterdam, 1660), which encouraged virtue and reminded the viewer of the transitoriness of life in contrast with death.

The combination of the single vanitas portrait paired off with a vanitas still-life became very popular visual imagery in Dutch art (Schama, 1987), and can be seen in Hendrick Goltzius's Man Holding a Skull and a Tulip of 1614, a drawing at the Pierpont Morgan Library in New York (Inv. III.145); and Antoine van Steenwinkel's Vanitas Portrait of the Painter of ca.1680, at the Royal Museum of Fine Arts in Antwerp (see Figures 7 and 8). These vanitas portrait paintings employed everyday objects (candle, coins, flowers, mirror, music instruments, and pipes) to imply didactic or moral messages. Erwin Panofsky coined the phrase "disguised symbolism" to refer to the meaning in this type of imagery (Panofsky, 1962; Panofsky, 1953). Nonetheless, the moral or religious connotations were clear and made coherent theological sense to the viewer (Haak, 1984; Schama, 1987). But the most powerful image associated with the skull, which was imbued with the symbolism of receptacle for life and for thought, and with the transmutation of human life (Cirlot, 1962), was the depiction of Homo bulla est (Man [the individual] is a bubble) as seen in Hendrick Goltzius's Quis Evadet? of 1594 at the Metropolitan Museum of Art in New York. The second part of this essay will analyze Goltzius's imagery in connection to the symbolism of the skull. 


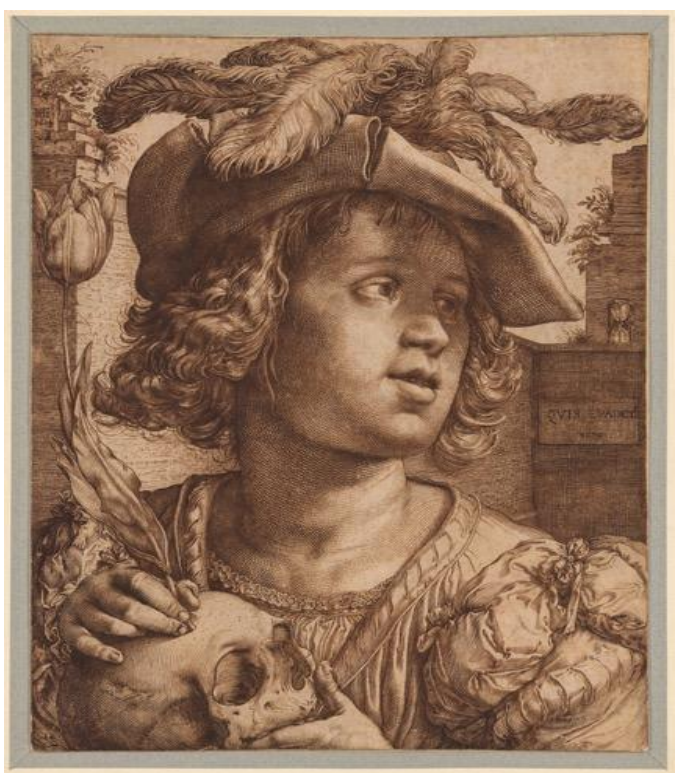

Figure 7. Hendrick Goltzius, Man Holding a Skull and a Tulip, 1614, drawing. Pierpont Morgan Library, NY. Photo credit: Pierpont Morgan Library, New York (Inv. III.145). Download image: 128202v-0001.jpg.

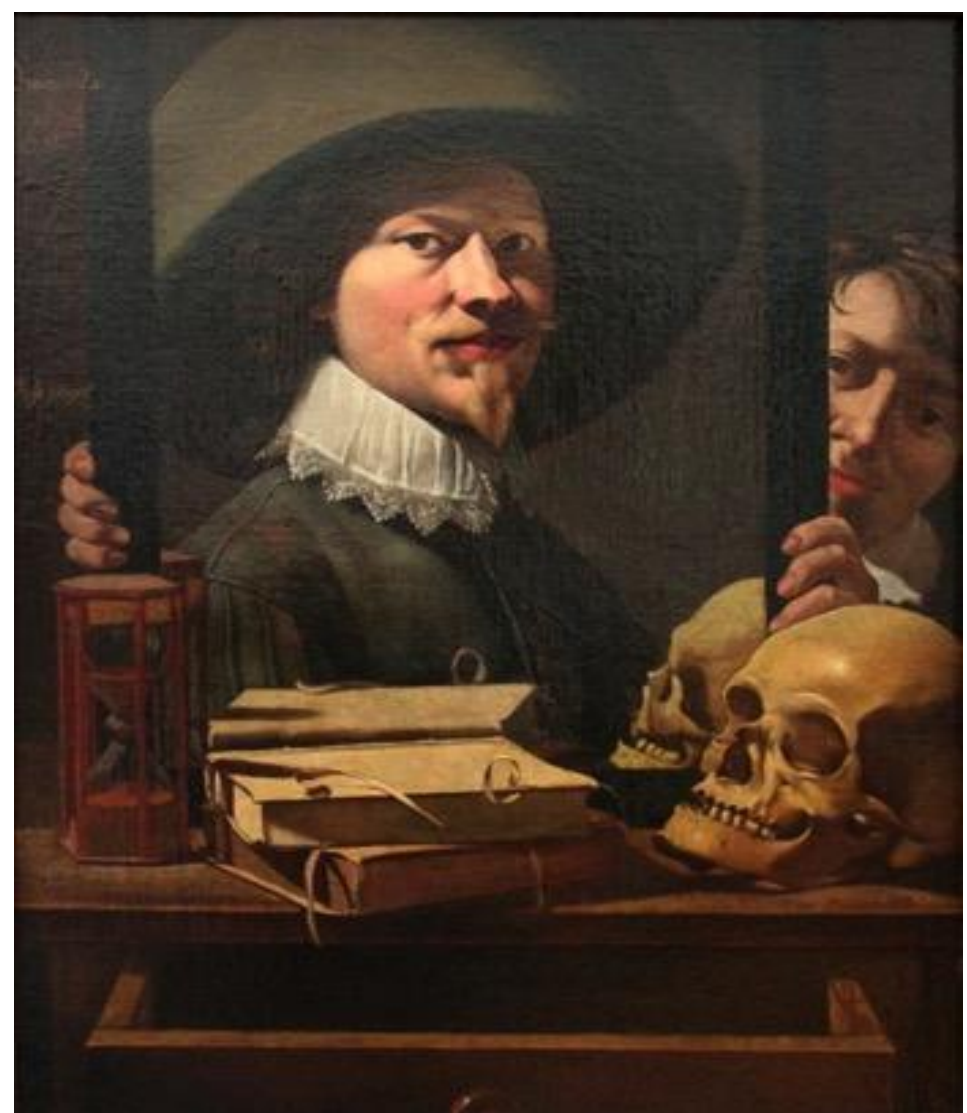

Figure 8. Antoine van Steenwinkel, Vanitas Portrait of the Painter, 1680. The Royal Museum of Fine Arts, Antwerp, Belgium (Photo credit: Public domain.commons.wikimedia.org). 


\section{Hendrick Goltzius's Homo Bulla Est (Man is a Bubble)}

Imageries of Homo bulla est (Man [the individual] is a bubble) are depictions of an open landscape where a putto or a naked youth rests on a skull while blowing soap bubbles. This imagery is commonly illustrated in European emblematic books and prints of the 16th and 17th centuries (Sutton, 2012; Cheney, 1992). This essay briefly examines the complex symbolism of air, as an ephemeral state, as a reference to the terrestrial passing of life (l'hora passa). In an anonymous Italian Renaissance woodcut, L'Hora Passa (Time Passes), 1490, at the Bibliothèque Nationale in Paris (see Figure 9), the motto l'hora passa, inscribed in a scroll at the top of the imagery, illustrates this concept (Janson, 1937) ${ }^{7}$. The scene represents, perhaps for the first time in Italian Renaissance art, the depiction of an hourglass with a wingless putto. The naked youth intensely gazes at the hourglass while resting on a large skull. He is meditating on the passing of time in a landscape surrounded with blooming and dead trees, scattered flowers, and insects-frogs and lizards (Janson, 1937; Seznec, 1938; Labno, $2016)^{8}$.

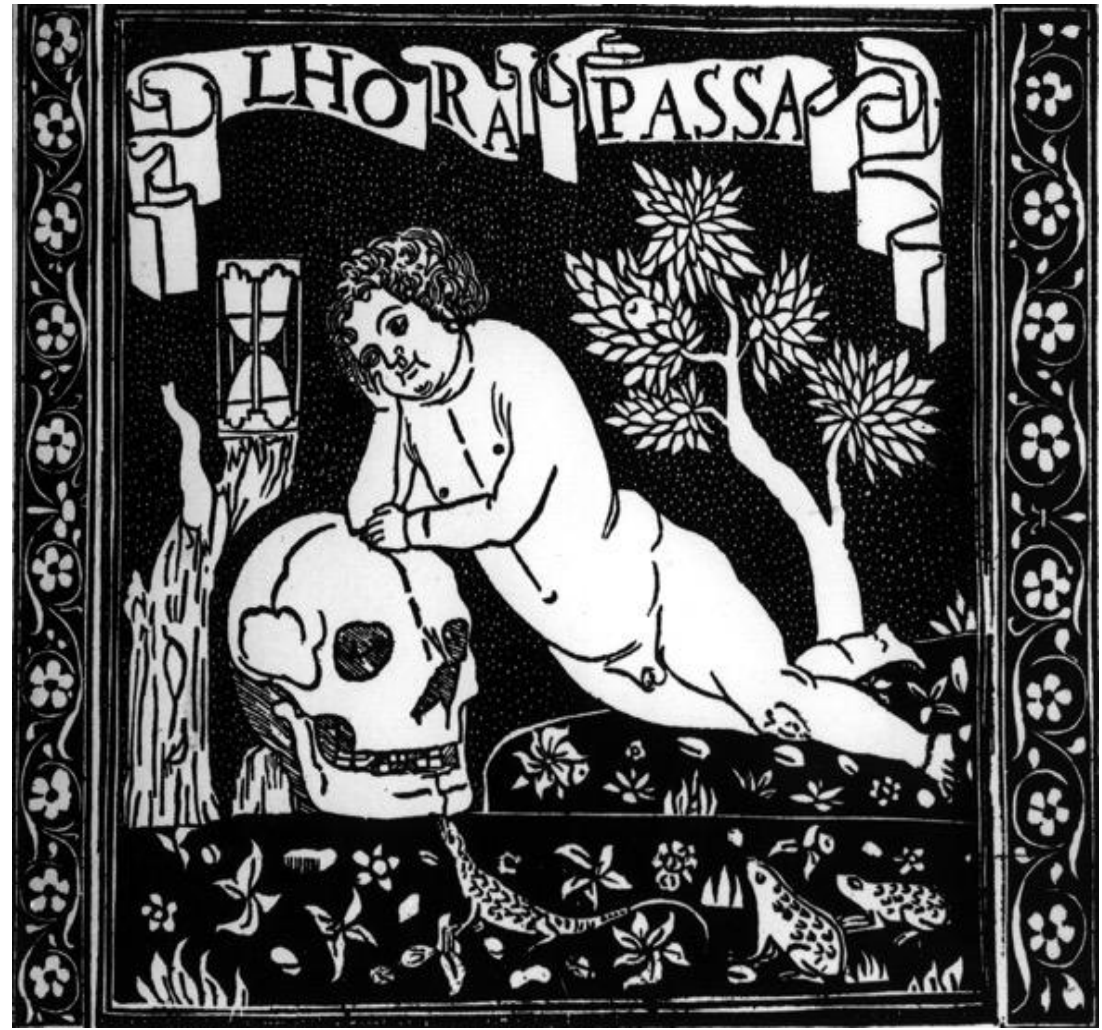

Figure 9. Anonymous, Italian Renaissance woodcut, L'Hora Passa, 1490. Bibliothèque Nationale, Paris. Photo credit: AKG Images (AKG255216).

\footnotetext{
${ }^{7}$ For an image of an anonymous German woodcut of 1530s representing a putto resting on a skull in a pictorial landscape.

8 Section on "Reframing the putto-and-skull motif: derivation, dissemination and formative influences", n.p.; and for images see: https://www.akg-images.co.uk/Docs/AKG/Media/TR3_-WATERMARKED/1/2/6/2/AKG286325.jpg (accessed June 15, 2018).
} 


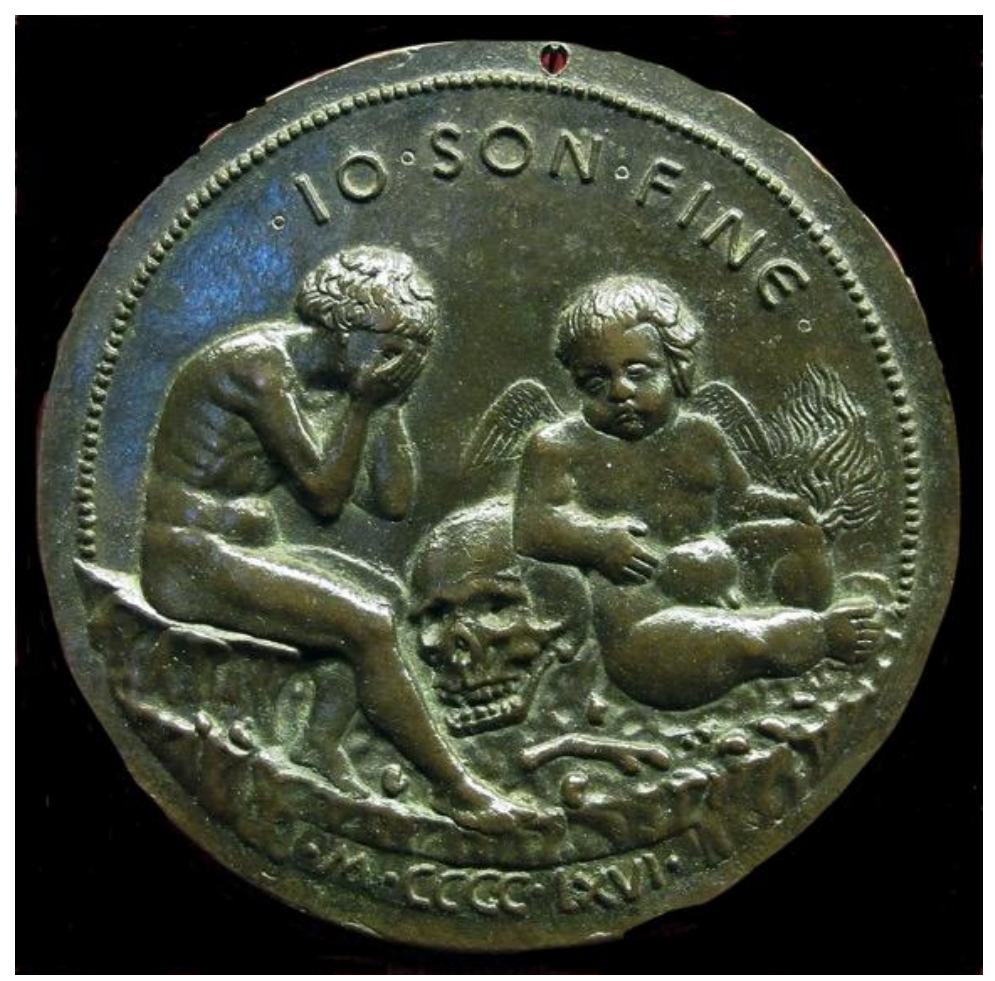

Figure 10. Giovanni Boldù, "Io Son Fine", medal verso from Roman Emperor Caracalla, 1490. Victoria and Albert Museum, London (Photo credit: Public domain.commons.wikimedia.org).

The moral allusion of L'Hora Passa is associated with an ancient proverb about the brevity of life. For example, the ancient Roman poet and writer, Marcus Terentius Varro (116-26 BCE), in Rerum Rusticarum (On Agriculture), Book Three, recalled a popular proverb: "Ut dicitur si est homo bullas, eo magis senex" (As they say, man is a bubble, all the more so is an old man) (Stechow, 1938).

In Dutch representations of Homo bulla est, the visual imagery derived from two sources: One is literary, from the Dutch humanist Desiderius Erasmus Roterodamus (1466-1536), who reinvented Varro's saying, Homo bulla est, in his Adages (A collection of Greek and Latin proverbs) in 1500 (Baker, 2001) ${ }^{9}$. The other is a visual source long associated with images deriving from the Italian Renaissance, in particular, the medal of the Venetian Giovanni Boldù's Roman Emperor Caracalla, at the Victoria and Albert Museum in London (Janson, 1937). The recto of the commemorative medal represents the bust head of the young emperor, while the verso refers to a historical memento mori with the Italian inscription IO SON FINE ("I am mortal" or "I am the end"), a motto similar to the L'Hora Passa about the certain fate of humankind, death. Below Boldù's inscription, in a rocky landscape, there is a seated naked man, probably the artist, covering his head in his hands, lamenting. In front of him the angel of death, a young winged putto with a sad expression, rests on a skull, and holds onto flames or a "bundle of flames, symbol of the soul" (Janson, 1937). Other bones are discarded throughout the landscape. This medal is dated 1466 (MCCCCLXVI) in the lower border (see Figure 10). During the Italian 16th century, Vincenzo Cartari (1531-1569), an Italian humanist and mythographer, adopted Boldù's image for

\footnotetext{
9 "Homo bulla est" (Man [the individual] is a bubble). The lesson of this proverb, Erasmus noted: "Is that there is nothing so fragile, so fleeting and so empty as the life of man. A bubble is that round swollen empty thing which we watch in water as it grows and vanishes in a moment of time".
} 
his book on Le Imagini delli Dei degli Antichi (Mulryan, 2012; Camin, 2002) ${ }^{10}$. Hence, Boldù's image was dispersed and popularized among emblematic and literati circles through emblems and prints in Europe.

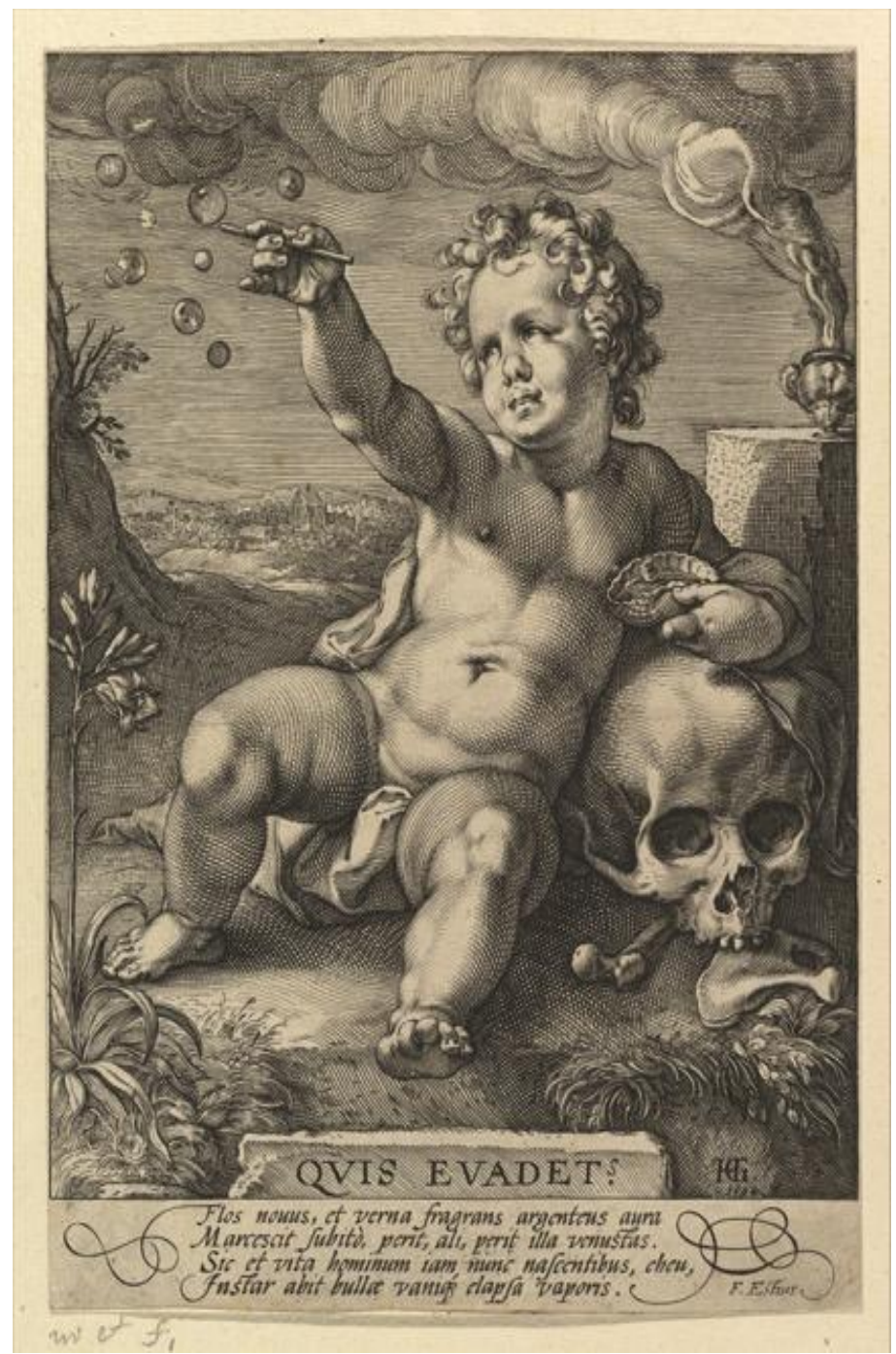

Figure 11. Hendrick Goltzius, Quis Evadet? I, 1594. Allegory of Transience (Homo bulla est). Metropolitan Museum of Art , New York (51.501.4929) (Photo credit: Metropolitan Museum of Art, New York). The Elisha Whittelsey Collection, The Elisha Whittelsey Fund, 1951.

In the Dutch imagery of Homo bulla est there is a sad child (homo) holding a scalloped shell filled with soap and water. Although the child is amused and playing with the formation of beautiful transparent water circles, his expression is mischievous and melancholic. This type of imagery is also accompanied by blooming flowers and dead trees, burning urns, and cloudy landscapes. Dutch artists and printmakers, such as Hendrick Goltzius (1558-1617) honored this proverb Homo bulla est in his print the Allegory of Transience (Homo bulla est),

\footnotetext{
${ }^{10}$ Published in Venice by Francesco Ziletti, 1556 and 1571. See image in the 1571 edition, 272, Fig. 47; Vincenzo Cartari's Images of the Gods of the Ancients: The First Italian Mythography.
} 
at the Metropolitan Museum of Art, Figure 3 (Strauss, 1977) ${ }^{11}$. The print is signed and dated on the lower right with the monogram HG, 1594.

The engraving represents a panoramic view of a landscape, where in the background there is a cityscape and in the foreground a rustic natural setting. A nude child, a Herculean putto, ponders with a puzzling expression. He is seated on the ground resting one arm on a skull and bones, holding a scalloped shell with water and soap in one hand. With the other hand, the curly-haired putto plays with bubbles formed from the water and soap. As he watches the formation of the beautiful clear bubbles floating in the air, he also sees them bursting, evaporating, and disappearing on their contact with natural air. $\mathrm{He}$ also experiences the fumes emerging from a burning urn, which is located on a marble pedestal behind him; they too vanish in mid air.

Metaphysically, the open sky or the air becomes a recipient of the water bubbles and fumes or smoke. Goltzius's humanistic awareness combined the physical elements of air, water, fire, and earth (the landscape, flowers, trees, and the putto), forming natural aspects of the cosmos with metaphysical notions about human life and death. The spiral or ascending movement of the smoke refers to the axis mundi, the "path of escape from time and space" (Cooper, 1987). The transformation of the body into ashes, like the soap and water into bubbles and the fire burning into flames, allude to the natural transformation of life. These phenomena are considered as part of the eternal and perpetual recurrence of death and rebirth, like the change of the seasons and the individual biological pattern of the ages of life- childhood, youth, adulthood, and old age (Chevalier \& Gheerbrant, 1994). In Christian religion, the human dilemma is in accepting one's mortality: that is, the separation of the natural body from the soul, and trusting the transformation of matter into a spiritual essence; hence, the soul traveling through air is purified through fire and water in order to arrive at the celestial realm (Grant, 2004; Cooper, 1987).

Goltzius's print shows the putto's extended leg pointing to a broken stone or epitaph in front of him, containing a Latin caption: QVIS EVADET? ("Who is saved [from death]?" or "Who evades [death]?"). Below it, in the lower margin there is a Latin poem. At the end of it are inscribed the letters F. Estius. A friend of Goltzius, the Catholic humanist and Neo Latinist, Franco Estius (1545-1594-47?), from Haarlem, composed many Latin poems for Goltzius's prints throughout his life, including this one:

Flos nouus, et verna fragrans argenteus aura

Marcescit subito, perit, ali, perit illa venustas.

Sic et vita hominum iam, nunc nascentibus, eheu,

Instar abit bullæ vanique elapsa vaporis. F. Estius

(The fresh silvery flower, fragrant with the breath of spring,

Withers once its beauty wanes;

Likewise the life of man, already ebbing in the newborn babe,

Vanishes like a bubble or like fleeting smoke. F. Estius. ${ }^{12}$

\footnotetext{
11 Engraving on laid paper, for image see: https://www.metmuseum.org/art/collection/search/363640. See also The New Hollstein Dutch \& Flemish Etchings, Engravings and Woodcuts, 1450-1700 (Rotterdam: Sound \& Vision Interactive, 1996): No. 128; The Complete Engravings and Woodcuts, 2 vols (Amsterdam: Abaris Books, 1977). Many of Goltzius's prints were copied by himself or other artists in painting, e.g., Hans von Aachen's Homo bulla est of 1628 (Christie's LotFinder: entry 5309550), for image see: https://commons.wikimedia.org/wiki/File:Kreis_des_Hans-_von_Aachen_-_Homo_bulla_est.jpg (accessed June 24 2018), after Otto Octavius van Veen's Homo bulla est of 1630s (Artnet Auction), for image see: http://www.artnet.com/artists/otto-octavius-van-veen/homo-bulla-est-a-vanitas-still-life-with-a-child-PWMqVj019y4zMacx95emk g2; and after Goltzius's Homo bulla est, see for image: http://www.artnet.com/artists/hendrik-goltzius/homo-bulla-est-0PGuHtqlng1KR1OAi9E1ZA2 (accessed June 24, 2018).

12 Golztius's motto derived from Franco Estius's poem as noted by the initials at the end of the inscription. See Klessmann, 1978, pp. 127, 175-177; Sutton, 2012, p. 139.
} 


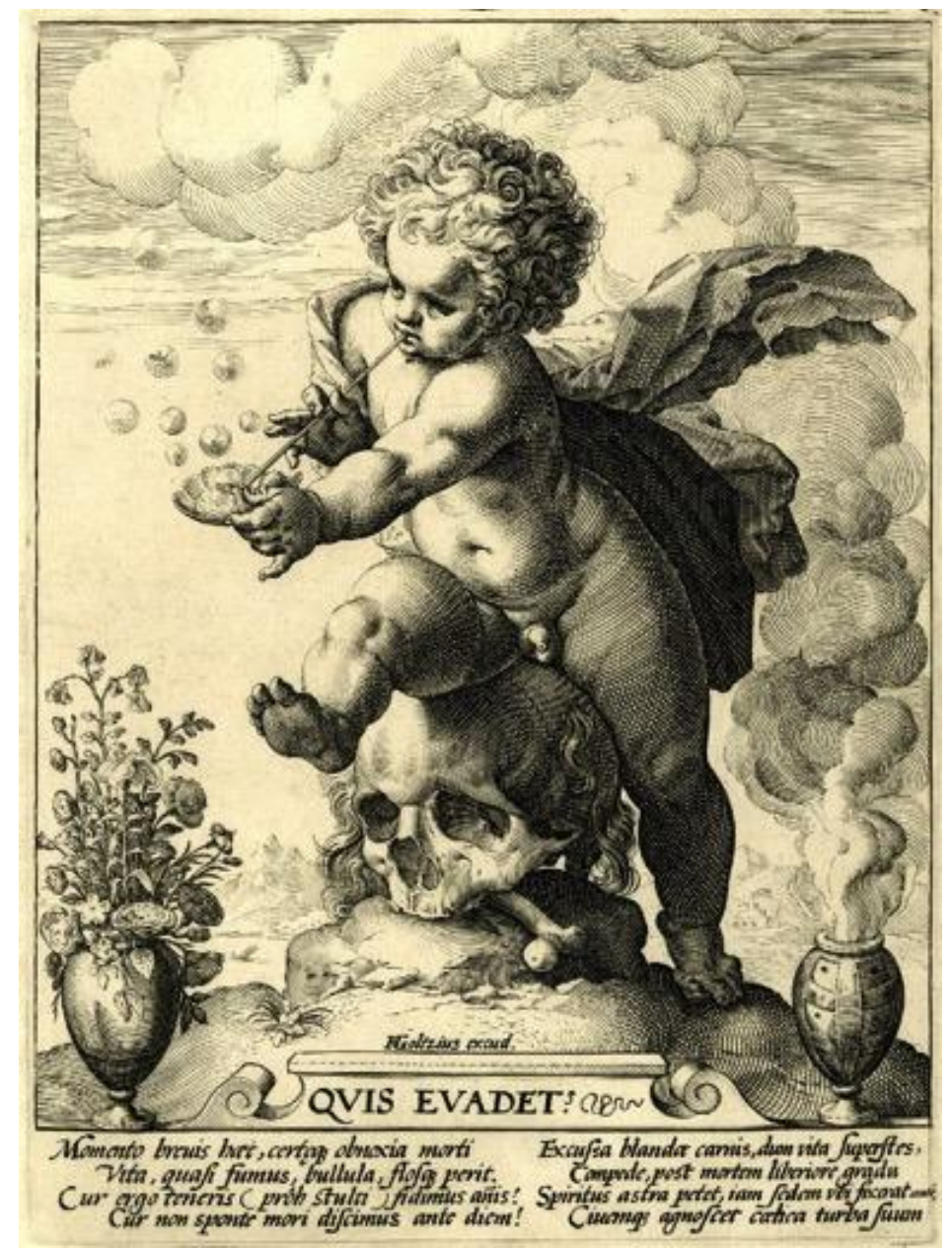

Figure 12. Hendrick Goltzius, Quis Evadet? II (Homo bulla est), 1590-94, After Agostino Carracci. Rijksprentenkabinet, Amsterdam (No. RP-P-OB-10.228).

In a more daring print, Goltzius represented also a panoramic landscape whose lower background illustrates a seascape and cityscape, while the foreground represents the top of a mountain (see Figure 12) (De Grazia, 1984). ${ }^{13}$ Here, Goltzius created another Herculean-type of putto who does not rest but eagerly rides on a skull

${ }^{13}$ For a discussion on the Bolognese Agostino Carracci's lost drawing or study of Quis Evadet engraved by his Bolognese collaborator Giuseppe Rosaccio. Probably this print was the source for the second version of Goltzius's Quis Evadet? In Rosaccio's print, the poem is written in Italian and not in Latin, suggesting that the poem was composes by Agostino Carracci or by Rosaccio. The poem laments:

Così passa qua giù l'humane pompe,

Così sparisce questa gloria frale;

Ogni mostro piacer Morte interrompe.

Vano è 'l disegno, e l'opera d'huom mortale,

Ecco l'esempio del fanciullo ch'indarno

S'industria: e'l faticar nulla gli valle.

(Thus does earthly pomp pass away,

Thus does human frailty disappear;

Death interrupts our every (monstrous) pleasure.

In vain do mortals toil and plan.

Ponder the instance of the youth who labors hard,

And his striving avails him naught.

[My translation with William Wanbaugh] 
that is still covered with human hair. The putto stands blowing bubbles directly from the soap dish. His expression is pensive but determined. Framing this composition at each corner is a vase with blooming flowers and an urn with a burning smoke. Goltzius has signed his plate with "H. Goltzius. excud". Below his signature, a classical stone scroll contains a Latin caption: QVIS EVADET. The Latin poem below the images reads:

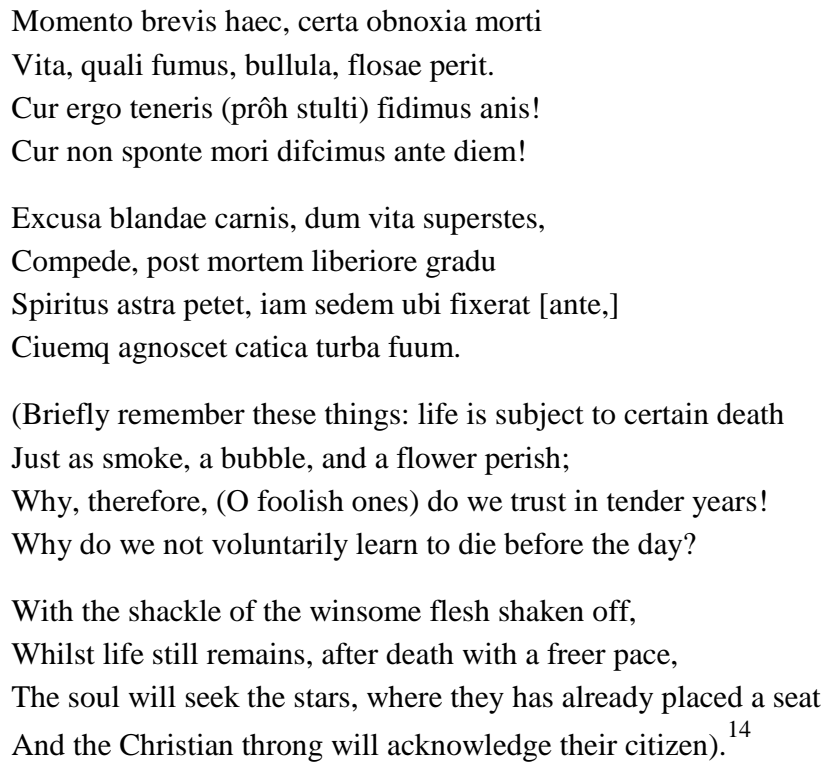

In this print, Goltzius ingeniously constructs a series of paragoni (comparisons) between the elements in the scene referring to the duality of the cosmos, life, mind, and nature (Hart, 1994; Biedermann, 1992); namely, the putto's curly hair is contrasted with the straggling hair still on the skull; the putto's curls are similar to the shape of the circular bubbles and to the spiral movements of smoke and clouds; and the skull clenches to a bone like the putto grasps onto a hollow tube (straw) to make his bubbles. In each side of the print's corners, there is an object that emits a scent: a vase of flowers with the aroma of perfume, and a burning urn with the smell of smoke. The bubbles evaporate in the air in the same manner as the scents. Goltzius continued to refer to the powers of the five senses in this imagery of Homo bulla est, e.g., for the sense of smell, flowers, and smoke; for touch, holding the scallop shell and resting on the skull; for sight, the Latin caption and inscription; for taste, the skull clenching onto a bone, the putto onto a tube; and for hearing, in a more abstract form, the sound of the atmosphere or the opposite, the lack of sound, silence. Goltzius's fascination with the iconographical meaning of the natural elements is well-documented in his cycles of the Four Seasons (Lauterbach, 2004/2005; Alpers, 1984), the Four Temperaments and the Five Senses between 1589 and 1601 (Strauss, 1977) ${ }^{15}$. With these cycles, the interaction is between a female and male but in the imagery of Homo bulla est the pairing is between a putto and a skull, life and death, the here and then.

The symbolism of the floating bubbles also derives from emblematic books from this period and engravings, for example, Hadrianus Junius's emblem XVI: Et Tutto Abbraccio, Et Nulla Stringo (I embrace everything, and hold nothing). The emblem shows many children trying to capture and hold on to floating bubbles (see Figure 13, compare with Figures 11 and 12) (Junius, 1565). Goltzius employed the shell as an ancient traditional symbol of cosmic death (birth, death, and rebirth) associated with the cycle of the moon and water (Chevalier \& Gheerbrant,

\footnotetext{
${ }^{14}$ I thank Dr. William Wanbaugh for assisting me with the Latin translation. Perhaps Estius composed also this moralizing poem. This Latin poem, although similar in sentiments, is not a translation or an adaptation of the Italian poem, see nn. 12 and 13.

${ }^{15}$ Notice that Goltzius's first name is written in two different ways by scholars: Hendrik or Hendrick.
} 
1994), while the scallop shell as a container of water and soap is a Christian iconographical symbol for purification commonly used in baptismal rituals (Metford, 1983). The scallop shell is also a symbol of pilgrimage referring to the journey of the human soul to achieve eternal salvation while traveling on the Earth (Cooper, 1987).

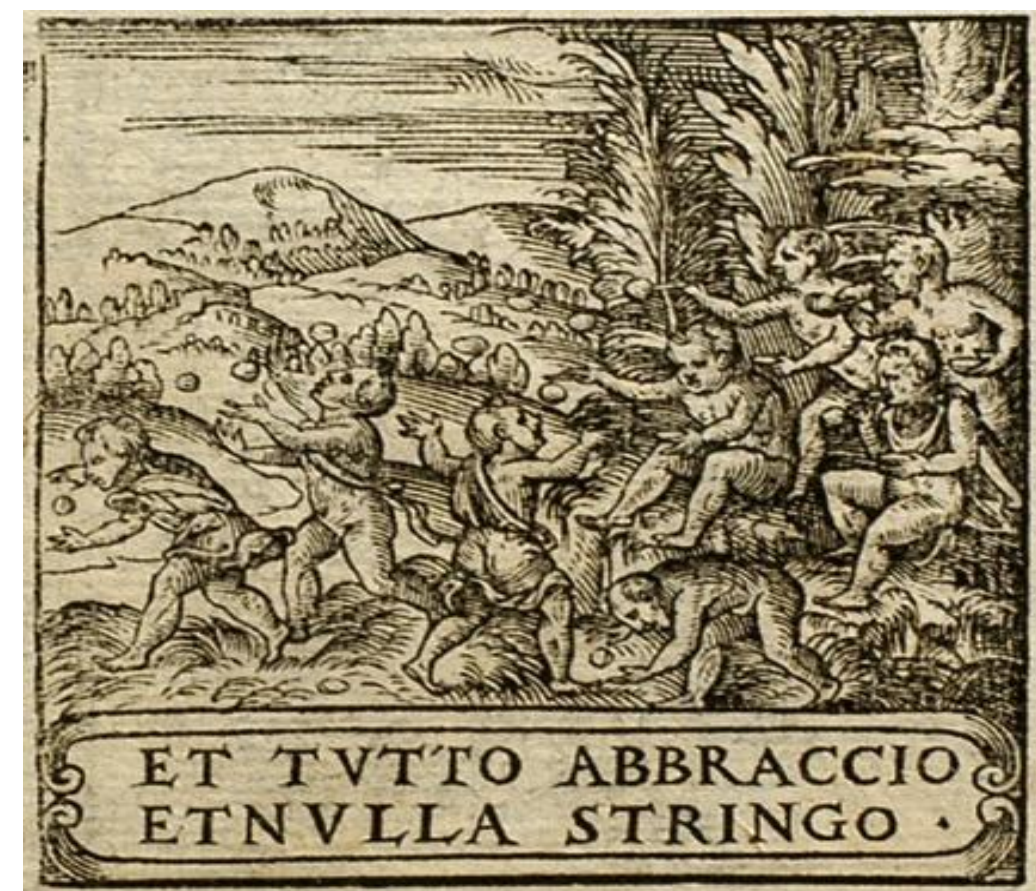

Figure 13. Hadrianus Janius, Emblem XVI, from Medici Emblemata (Antwerp: Christophe Plantin, 1565) (Photo credit: Public domain.Interactive Archive.wikipedia.org).

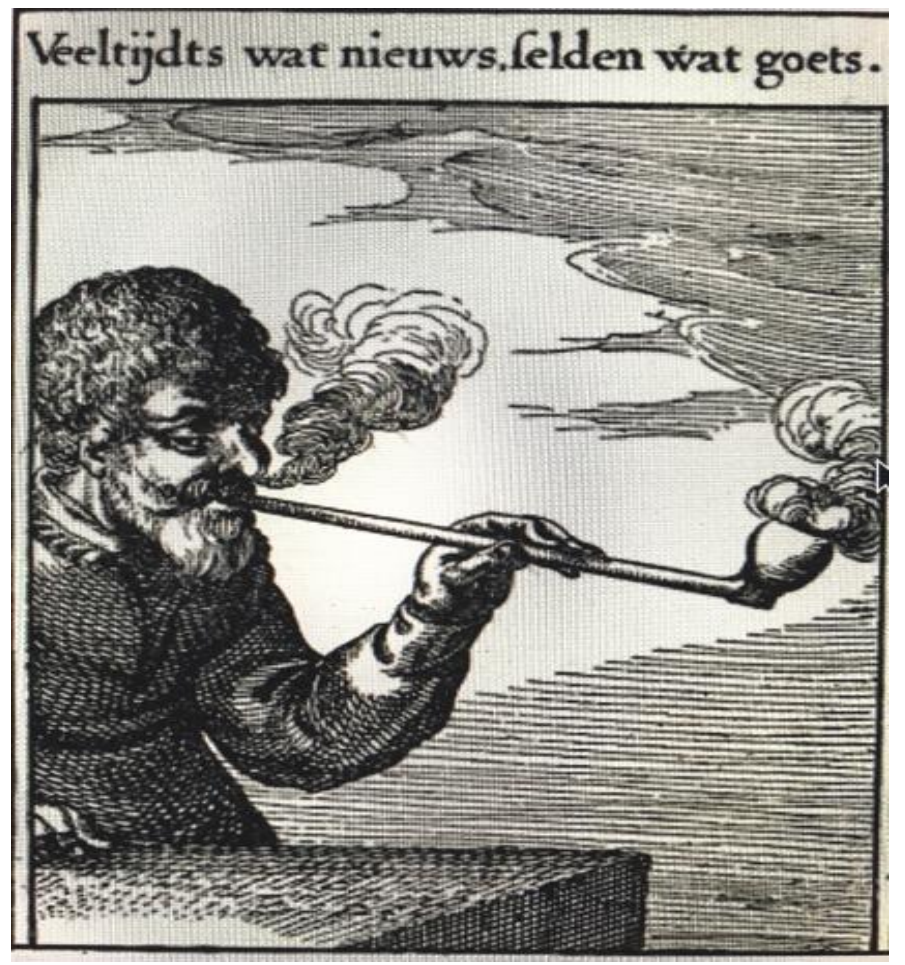

Figure 14. Roemer Visscher, Emblem X, from Sinnepoppen (Amsterdam: Claes Jansz Visscher, 1614). Photo credit: Digitale Bibliotheek voor de Nederlandse letteren (Hague: Martinus Nijhoff, 1949, p. 132). 
The meaning of the transience of life represented by soap bubbles is paralleled by the evanescent perfume of the lily flower, located in front of the putto, and the smoke of a burning urn behind him (Chevalier \& Gheerbrant, 1994; Kuretsky, 1987) ${ }^{16}$. Later, the action of smoking becomes an emblematic motif for the Dutch humanist and poet, Roemer Visscher, in his book Sinnepoppen, with the motto "X: Veel tijds wat nieuws, selden wat goets" (Often something new, seldom anything good) (see Figure 14). The emblem illustrates a seated man smoking tobacco while puffing a large clay pipe (Gibson, 2000) ${ }^{17}$. His action refers to the biblical warning: "My days are consumed like smoke" (Psalms CII:3). A similar Biblical warning for the putto blowing bubbles, alludes to vanitas and the superficiality of living as well as the brevity of human existence as the bubble evaporating in mid air (Ecclesiastes 1:2) (Schama, 1988) ${ }^{18}$.

The landscape, the flowers, and the skull are all earthly symbols of change and metamorphosis through natural cycles of time; while the bubble, the cloud, and the smoke are alterations caused by quick interventions, causing evaporation or fading in a moment. Thus, humankind is part of a cyclical evolution visualized with the putto and the skull, while the individual's desires and passions as fleeting experiences are visualized as bubbles and smoke. However, the allusion is positive and didactic, inspiring viewers (individuals) to focus on the mortality of the being in order to realize their full potential as a person, and to aspire toward spiritual goals and not material pursuits because, like bubbles or smoke, they quickly evaporate into a vacuum as the pursuit of vanitas.

\section{Conclusion}

During the controversial European period of the reformation and counter-reformation, the quest of emblems books and prints were to instruct and moralize although later these intentions changed as well as their function, becoming popular media in some instances (MacCulloch, 2005; Hillerbrand, 2009). Emblem books for children's pastimes were composed where the now clothed youth played with bubbles, while the skull disappeared with its moral implications of vanitas and the transience of life. The physical and metaphysical complexity of the individual's quest for the meaning of life is lost. Child's delights and the joie de vivre (joy of living) are visualized in Judith Leyster (1609-1660)'s A Boy Blowing Bubbles of 1655-60 (see Figure 15) (Welu \& Biesboer, 1993; Hofrichter, 1989) ${ }^{19}$. In the painting a young boy, wearing a large straw hat decorated with a fancy black plumage, has stopped playing and making bubbles to provocatively smiles at the viewer. The mischievous facial expression is accompanied by his finger's gesture. In a paradoxical manner, the suggestive innuendo focuses more on the brevity of life and the thirst to satisfying human passions than on pondering on l'hora passa. In this type of imagery the moral allusion is absent but the desire for human's transgression is vivid, thus a variant on Homo bulla est.

\footnotetext{
16 The lily flower also alludes to the putto's innocence and purity of heart.

17 Willem Iansz published the book in Amsterdam in 1614. The engraver of the etchings for the book was Claes Jansz Visscher. Digitized by the Bibliotheek voor de Nederlandse letteren (Hague: Martinus Nijhoff, 1949, p. 132).

18 Translated according to the King James Bible as "Vanity of vanities, said the Preacher, Vanity of vanities! All is vanity;" or in the Jerusalem Bible as "Vanity of vanities, said Ecclesiastes: vanity of vanities and all is vanity."

19 The painting was sold by Christie's London, 24 March 2009, Lot 94. Now is in a private collection.
} 


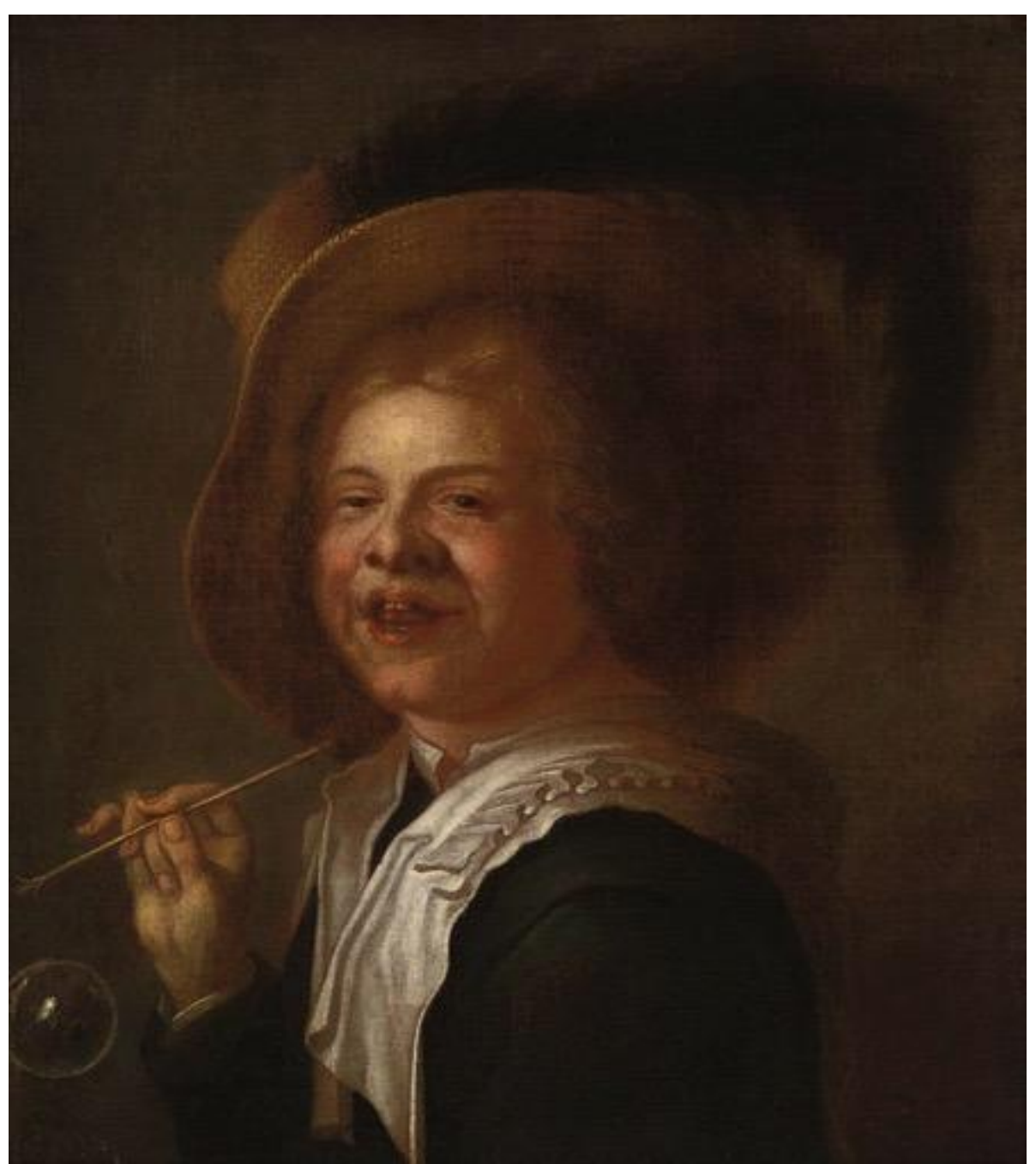

Figure 15. Judith Leyster, A Boy Blowing Bubbles, 1655. Christie's London, 24 March 2009, Lot 94. Public domain: commons.wikimedia.org.

\section{References}

Adams, A. J. (2013). The temporality and the seventeenth-century Dutch portrait. Journal of Historians of Netherlandish Art, 5(2), $1-30$.

Alciato, A. (1621). Emblemata. Padua: Petro Paulo Tozzi. Retrieved July 4, 2018, from https://www.emblems.arts.gla.ac.uk/alciato/emblem.php?id=A21a157

Alciato, A. (1985). The Latin emblems, indexes and lists. (P. M. Daly, Ed.). Toronto: University of Toronto Press.

Alpers, S. (1984). The art of describing: Dutch art in the seventeen century. Chicago, ILL: University of Chicago Press.

Baker, W. W. (Ed.). (2001). The adages of Erasmus. Toronto: The University of Toronto Press.

Bergstrom, I. (1989). Still lifes of the golden age. Washington, D.C.: National Gallery of Art.

Biedermann, H. (1992). Dictionary of symbolism: Cultural icons and the meanings behind them. New York, N.Y.: Meridian Books.

Boeckl, C. M. (1991). Triumph of death (Ph.D. dissertation, Columbia University). Retrieved July 4, 2018, from http://special.lib.gla.ac.uk/exhibns/death/deathhome.html

Bremmer, J., \& Roodenburg, H. (1991). A cultural history of gesture. Groningen: University of Groningen/UMCG.

Camin, G. (2002). "Finis ab origine pendet", Lorenzo Lotto, George Wither e il puer della rinascita ("The End is the beginning": Lorenzo Lotto, George Wither and the fear of rebirth). Retrieved June 24, 2018, from http://www.engramma.it/eOS/index.php?id_articolo=2504 
Causey, F. (1993). Skulls and skeletons in Roman art. In L. D. Cheney (Ed.), Symbolism of vanitas in the arts, literature, and music: Comparative and historical studies (pp. 103-113). Lewiston, NY: The Edwin Mellen Press.

Cheney, L. D. (Ed.). (1992). The symbolism of vanitas in arts, literature and music: Comparative and historical studies. Lewiston, NY: Mellen Press.

Chevalier, J., \& Gheerbrant, A. (1994). A dictionary of symbols. London: Blackwell.

Chong, A. (Ed.). (1999). Still-life paintings from the Netherlands, 1550-1720. Zwolle: Waanders Publishers.

Cirlot, J. E. (1962). Symbols. New York, N.Y.: Philosophical Library.

Clark, J. M. (2016). Dance of death. Glasgow: Jackson, Sons \& Co.

Cooper, J. C. (1987). An illustrated encyclopedia of traditional symbols. London: Thames and Hudson.

De Grazia, D. (1984). Le stampe dei Carracci con i disegni, le incisioni, le copie e i dipinti connessi (Carracci's prints with drawings and engravings, copies and related paintings). Bologna: Alfa.

Engelgrave, H. (1655). Lux evangelica (Evangelic light). Cologne: Jacob de Meurs.

Gibson, W. B. (2000). Pleasant places: The rustic landscape from breughel to ruisdael. Berkeley, CA: University of California Press.

Grant, E. (2004). Science and religion 400 B.C. to A.D. 1550. Baltimore, MD: John Hopkins University Press.

Guazzoni, V., Tanzi, M., \& Frangi, F. (Eds.). (2017). Genovesino: Nature and invention in Cremona's paintings of the seventeenth century. Milan: Officina Libreria SRL.

Haak, R. (1984). The golden age. New York, N.Y.: Harry N. Abrams.

Hall, J. (1974). Dictionary of subjects and symbols in art. New York, N.Y.: Harper \& Row, Publishers.

Hart, W. D. (1994). Dualism. In S. Guttenplan (Ed.), A companion to the philosophy of mind (pp. 265-269). Oxford: Basil Blackwell.

Hecht, P. (1986). The debate on symbolism and meaning in Dutch seventeenth-century art: An appeal to common sense. Simiolus: Netherlands Quarterly for the History of Art, 16(2/3), 173-187.

Hillerbrand, H. J. (2009). The protestant reformation. New York, N.Y.: Perennial/Harper Colllins Publishers.

Hind, A. M. (1963). A history of woodcut. New York, N.Y.: Dover Publications, Inc.

Hofrichter, F. F. (1989). Judith Leyster: A woman painter in Holland's golden age. Doornspijk: Davaco.

Janson, H. W. (1937). Putto with death's head. Art Bulletin, 19(3), 423-449.

Junius, H. (1565). Medici emblematic. Antwerp: Christophe Plantin. Retrieved June 24, 2018, from https://www.emblems.arts.gla.ac.uk/french/books.php (accessed June 24, 2018)

Kelly, R. J. III. (2006). To be, or not to be: Four hundred years of vanitas painting. Flint, MI: The Flint Institute of Arts.

Klessmann, R. (1978). Die sprache der bilder (The language of images). Braunschweig: Anton Ulrich-Museum.

Kuretsky, S. D. (1987). Het schilderen van bloemen in de 17de eeuw (Paintings about flower in the 17th century). In Flora et Pictura (pp. 84-87). Kunstschrift Openbaar Kunstbezit.

Labno, J. (2016). Commemorating the Polish Renaissance child: Funeral moments and their European context. New York, N.Y.: Routledge.

Lauterbach, C. (2004/2005). Masked allegory: The cycle of the four seasons by Hendrick Goltzius, 1594-95. Simiolus: Netherlands Quarterly for the History of Art, 31(4), 310-231.

MacCulloch, D. (2005). The reformation: A history. Baltimore, MD: Penguin Books.

Metford, J. C. J. (1983). Dictionary of Christian lore and legend. London: Thames and Hudson.

Mulryan, J. (Ed. and Trans.). (2012). Vincenzo Cartari's images of the gods of the ancients: The first Italian mythography. Tempe, AZ: Arizona Center for Medieval and Renaissance Studies.

Panofsky, E. (1953). Early Netherlandish paintings. Cambridge, MA: Cambridge University Press.

Panofsky, E. (1962). Studies in iconography. New York, N.Y.: Harper \& Row.

Panofsky, E. (1972). The life and art of Albrecht Dürer. Princeton, NJ: Princeton University Press.

Porteman, K. (1993-1994). From first sight to insight: The emblem in the Low Countries. The Low Countries, 1, $212-222$.

Schama, S. (1987). The embarrassment of riches. New York, N.Y.: Alfred A. Knopf.

Schama, S. (1988). The embarrassment of riches: An interpretation of Dutch culture in the golden age. Berkeley, CA: University of California Press.

Segal, S. (1989). A prosperous past: The sumptuous still-life in the Netherlands 1600-1700. Cambridge, MA: Harvard University Press.

Seznec, J. (1938). Youth, innocence and death. Journal of the Warburg and Courtauld Institutes, 1(4), 298-303. 
Stechow, W. (1938). Homo bulla. Art Bulletin, 20(2), 227-228.

Strauss, W. L. (1977). Hendrik Goltzius, 1558-1617: The complete engravings and woodcuts (Vol. 2). Amsterdam: Abaris Books. Sutton, E. A. (2012). Early modern Dutch prints of Africa. New York, N.Y.: Routledge.

Visscher, R. (1614). Sinnepoppen (Symbolic pictures). Amsterdam: Claes Jansz Visscher.

Welu, J. A., \& Biesboer, P. (1993). Judith leyster: A Dutch master and her world. New Haven, CT: Yale University Press.

Alciato, A. (1591). Emblemata. Leiden: Platin. Retrieved July 4, 2018, from https://www.emblems.arts.gla.ac.uk/alciato/emblem.php?id=A91a156 